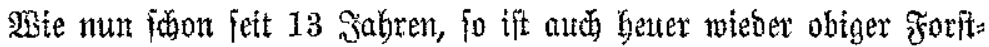

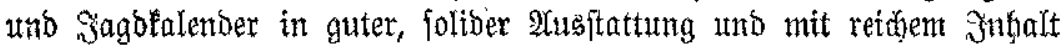
exjdienen. Reben einem Termingfalender uno einem Sagófalender, ber bie Sauk uno begezeiten aller bentionen Stanten angiebt, btetet berielbe

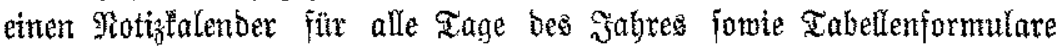

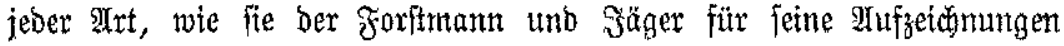

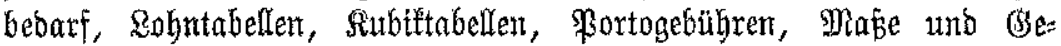
midgte U. f. w.

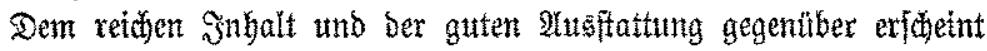

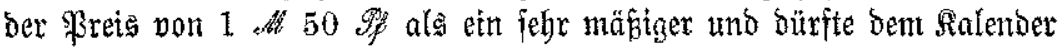

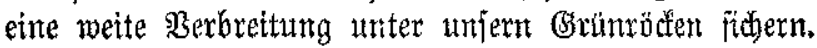

\title{
IV. Mltotiz̧en.
}

Thafuregel gegen Agarieus melleus in Bayern inr 18. Jaḩhundert.

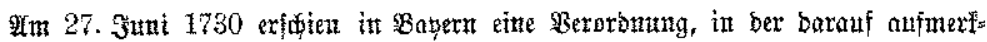

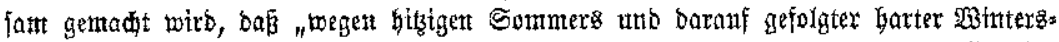

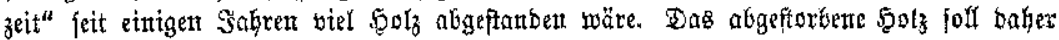

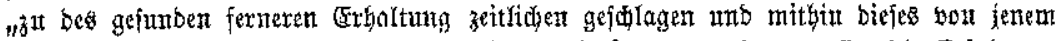
mit Madultg einiger tieferen (sa

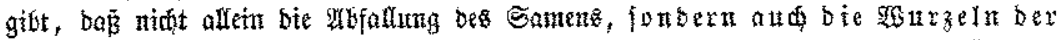

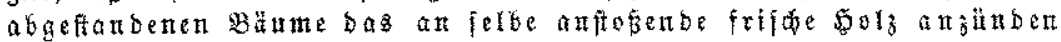

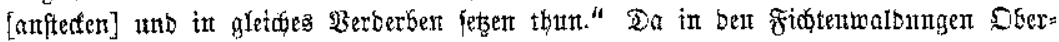

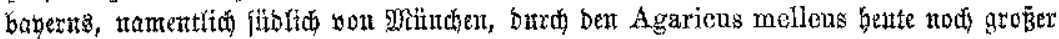
So Die bas ,

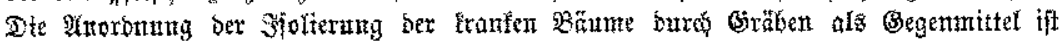

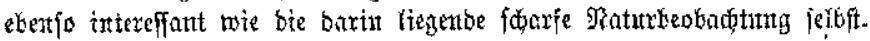

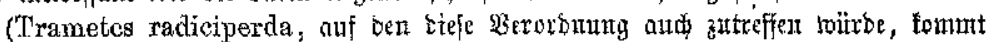

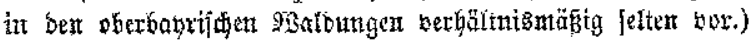

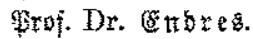

\section{(beiftliche als foritbeamte.}

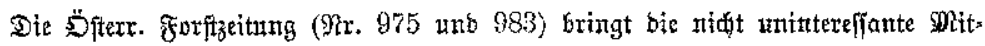

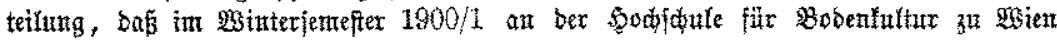

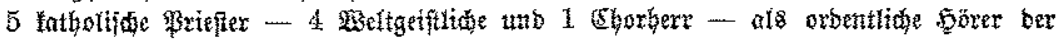

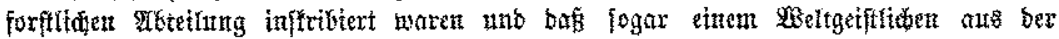

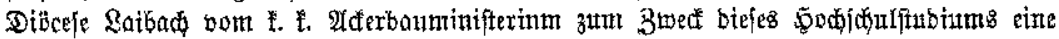

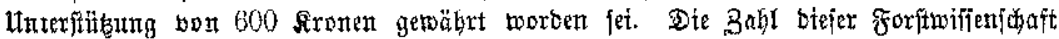

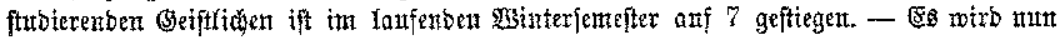

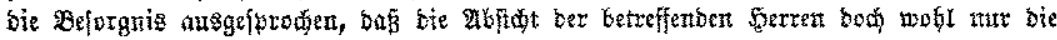

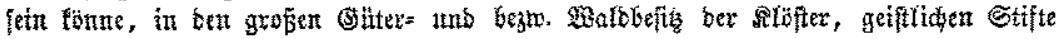

